\title{
Diálogos possíveis. As ambiguidades da vida em Paul Tillich e Ingmar Bergman
}

\author{
Frederico Pieper*
}

\begin{abstract}
RESUMO
Esse texto explora a relação entre linguagem cinematográfica e filosófica para se pensar a religião. Dessa perspectiva, o artigo propõe um diálogo entre Paul Tillich e o cineasta Ingmar Bergman sobre a constituição de si e o lugar do religioso nesse processo. Ambos concebem a vida como marcada pela ambiguidade, propondo o amor como possibilidade de superação do isolamento de si. Apesar das divergências no que concerne ao lugar da religião nesse processo, Bergman nos permite entrever a dificuldade existencial daquilo que Tillich pensa teoricamente.
\end{abstract}

Palavras-chave: religião; moralidade; cinema.

\section{Possible Dialogues.}

\section{The Ambiguities of Life according to Paul Tillich and Ingmar Bergman}

\begin{abstract}
This text explores the relationship between cinematic and philosophical language to think religion. From this perspective, the article proposes a dialogue between Paul Tillich and the filmmaker Ingmar Bergman on the constitution of the self and the place of the religious in this process. Both conceive life as ambiguity, proposing love as a possibility of overcoming self-isolation. Instead of divergences regarding the place of religion in this process, Bergman allows us to glimpse the existential difficulty of what Tillich thinks theoretically.
\end{abstract}

Keywords: Religion; morality; film.

* Bacharel em Teologia (EST-ICSP), em História (USP) e em Filosofia (USP). É mestre e doutor em Ciências da Religião (UMESP) e doutor em Filosofia (USP). É professor do Departamento de Ciência da Religião da Universidade Federal de Juiz de Fora (UFJF). Currículo Lattes disponível em: http://lattes.cnpq.br/4770309851004817. 
No Brasil, um dos encontros principais sobre o pensamento de Tillich traz por nome Seminário em Diálogo com o pensamento de Paul Tillich, no qual uma versão preliminar desse texto foi discutida. A feliz escolha do termo "diálogo" expressa que mais do que reproduzir as ideias desse pensador, o objetivo central desses seminários tem sido estabelecer uma conversa. E, como em todo diálogo, os interlocutores saem alterados. O texto de Tillich não é mais o mesmo após a inteiração com ele, como também não o são nossas perspectivas inicias. Além do mais, para a inteiração progredir, é fundamental que aqueles que se engajam numa conversa tenham interesses comuns. Com isso, não estou dizendo que devem ter opiniões semelhantes. Simplesmente quero indicar algo que todos sabemos de nosso cotidiano: sem interesses compartilhados, a conversa não flui.

Nesse espírito, gostaria de não somente dialogar com Tillich, mas de propor uma aproximação entre ele e o cineasta sueco Ingmar Bergman. Essa proposta tem relação com o interesse que a linguagem cinematográfica tem despertado para se pensar a religião. Para além dos textos, as imagens em movimento também revelam mundos, criam teorias, perspectivas e interpretações da religião. Nesse sentido, essa linguagem mais próxima da imagem e do movimento do que do discurso, revela-se como importante fonte de interlocução (Cf. PIEPER, 2015).

Quanto ao diálogo entre Tillich e Bergman, ele é viável devido, pelo menos, às seguintes razões: 1) Tillich se mostra sempre muito atento à produção artística, reconhecendo nela uma rica fonte de seu pensar. Mesmo que não tenha se dedicado especificamente ao cinema, acabou por inspirar marcos teóricos importantes nesse âmbito de pesquisa (JONHSTON, 2000; SKRADE, 1970; SANTOS, 2006); 2) Bergman, por sua vez, tem sido reconhecido como espécie de cineasta-filósofo, especialmente ligado ao que se denominou genericamente de existencialismo ${ }^{1}$. Várias das abordagens sobre seus filmes adotam essa perspectiva (BRANCO, 2014; LIVINGSTON, 2009). De igual modo, é sintomático de que ele,

\footnotetext{
Não pretendo aqui discutir a pertinência ou não desse nome. Entendo que há limites e problemas no seu emprego. No entanto, para os fins desse texto, peço ao leitor que conceda que há certos temas recorrentes na filosofia continental do século XX que busca ressaltar aspectos da existência, muitas vezes inspirados na primeira parte de Ser e tempo, na qual Heidegger propõe sua analítica existencial.
} 
assim como Tillich, busca tratar dos dramas humanos em articulação com referências religiosas. Em muitos de seus filmes, temáticas de cunho religioso são recorrentes. De menor importância, mas que vale ser mencionado, ambos cresceram em ambiente marcado pelo luteranismo. 3) Por fim, tanto Tillich quanto Bergman, a partir dessa moldura, tocam em questões centrais do século XX. A pergunta pelo sentido, e pela possibilidade de superação da falta de sentido (niilismo) e dos dilemas que essa época desperta, aparecem formuladas. E aqui, novamente, encontramos afinidades entre eles. Afinal, essas grandes questões, em ambos os casos, não recebem tratamento distanciado. Elas, até mesmo pelo reconhecimento de seu peso e de sua urgência, são situadas na concretude da vida. $\mathrm{O}$ fato de tratarem de muitas dessas questões, entretanto, não significa que concordem nas soluções alcançadas. É justamente aqui que o diálogo se torna mais interessante.

Ao traçar os pontos de afinidade, chegamos ao recorte que nos interessa nesse texto. Tanto Tillich como Bergman tratam dessas questões fundamentais do século XX. Por isso mesmo, a abordagem que ambos oferecem da vida busca evitar descrições inocentes. Isso quer dizer que, tanto em um como em outro, a vida é apresentada como permeada por ambiguidades. Nesse ensaio, interessa-nos mais proximamente a ambiguidade que se expressa na função da moralidade, isto é, da constituição do eu na relação com o outro. Como já fica claro, moralidade não tem aqui sentido restritivo, como se fosse meramente conjunto de regras a serem observadas ou mesmo como padrão de comportamento socialmente aceito. A noção assume sentido bem mais profundo: tem a ver com a constituição do indivíduo. E, nesse processo, a relação com o outro é decisiva. Ao se reconhecer isso, despontam algumas questões: como se dá essa relação com o outro? Em que medida, para ambos, o amor pode se mostrar como possibilidade de redenção frente às ambiguidades da vida? $\mathrm{E}$, por fim, uma pergunta que sempre emerge quando se trata desses temas: até que ponto é possível superar essas ambiguidades e qual o papel da religião?

\section{O lugar e a noção de ambiguidade em Tillich}

A fim de chegar à questão da moralidade em Tillich, onde a relação com o outro se situa, é importante localizá-la no seu pensa- 
mento. Isso quer dizer que é significativo observar quais os conjuntos de temas e problemas ela pressupõe e mobiliza. Ainda que não se reconheça como um pensador existencialista, é bastante claro que a perspectiva a partir das condições concretas é determinante para o pensamento de Tillich. Quando se observa sua obra principal, Teologia sistemática, é evidente como os três grandes movimentos que a ordenam correspondem a três conceitos centrais para indicar a condição humana: finitude, alienação e ambiguidade.

No âmbito na finitude, o ser humano se sente ameaçado pelo não-ser. A religião, por sua vez, responde a essa questão existencial apontando para Deus como base criativa a partir da qual o ser humano pode superar essa ameaça. Isso se dá por meio da afirmação da coragem de ser. Já na existência alienada, o ser humano busca o fundamento de seu ser. Essa pergunta pelo novo ser encontra em Jesus como o Cristo sua resposta, religando o ser humano ao seu fundamento. E, por fim, aparece a pergunta pela vida. Enquanto é mistura de essência e existência, a vida é marcada pela ambiguidade. A pergunta que surge dessa situação do ser humano é pela vida sem ambiguidade, no sentido de superar essa tensão que se instaura no interior da vida.

A ambiguidade é tratada com mais detalhes apenas na terceira parte da Teologia sistemática. Há uma razão de ser para isso. As partes anteriores da obra ofereciam o aparato para que Tillich pudesse retomar o tema nesse momento da obra. A atenção da primeira parte da Teologia Sistemática se dirige à noção de ser; já, na segunda, a existência é considerada de perto. E, na terceira parte, "Estamos, aqui, usando a palavra 'vida' no sentido de uma 'mistura' de elementos essenciais e existenciais" (TILLICH, 2005, p. 476), isto é: a ambiguidade da vida pode ser abordada quando as duas noções que ela pressupõe (essência e existência) já foram devidamente delineadas.

A essência diz respeito àquilo que faz com que algo seja. Em outros termos e no caso que aqui nos interessa, Tillich entende que a essência comporta certa dimensão prescritiva. Ela aponta para aspectos estruturantes que dizem o que é o ser humano em sua natureza. Nessa situação ideal, o ser humano é unidade com o fundamento do ser, isto é, com Deus. É curioso observar como Tillich sobrepõe essência e poder ser. Com relação ao ser humano, a sua essência diz respeito ao que ele 
deve/pode ser. Esse estado, no entanto, é muito diferente de dizer o que ele atualmente de fato é.

A existência, por sua vez, designa aquilo que o ser humano efetivamente é. Desse modo, ele poderia estar unido ao seu fundamento (essência), mas, nas condições atuais, ele não se encontra nessa situação (existência). Enquanto a essência nos mostra aquilo que deveríamos ou poderíamos ser, a existência nos revela o que efetivamente somos. Quando observarmos panoramicamente a Teologia sistemática, ela entende que a existência é marcada por certa decadência. Decadência não em sentido moral ou ético, mas ontológico. Isso significa dizer que o ser humano, sob as condições da existência, encontra-se afastado de seu fundamento. Esse afastamento é nomeado por Tillich como alienação.

É interessante notar que Tillich recorre a algumas figuras da tradição judaico-cristã para ilustrar esses dois estados. O ser humano essencial encontra sua figuração em Adão, no seu estado de inocência. Essa figura mitológica nos mostra que no estado de inocência pré-queda, o ser humano se encontra em união com o fundamento divino e consigo mesmo. Nessas condições, essência e existência coincidem: aquilo que o ser humano deveria ser se conforma ao que efetivamente ele é (TILLICH, 2005, p. 509). Essa perfeita adequação, entretanto, é rompida quando o ser humano se afasta de seu fundamento. Isto é, uma vez que o ser humano se encontra alienado do fundamento divino, reconhecendo-se como distinto do fundamento de seu ser, instaura-se uma cisão. $\mathrm{O}$ termo religioso pecado nada mais é do que o modo de dar expressão a essa fratura que se instaura entre a essência e a existência. O ser humano já não é o que deveria ser. Isso, entretanto, não significa que ele não tenha ciência de sua essência. Ele a reconhece. Mas, ela já lhe parece distante.

Portanto, é justamente no amálgama entre essência e existência que se encontra a noção de vida como ambiguidade em Tillich. A vida não pode, dessa maneira, ser descrita como totalmente dominada pelas condições da alienação. Resta ainda uma lembrança da essência. Quando se dá atenção a isso, percebe-se como Tillich é cuidadoso na escolha dos termos. Ele emprega a palavra vida, e não somente existência como o fazem alguns "existencialistas". Ao fazer esta opção, fica-se apenas com um lado do problema e não se pode entendê-lo em sua amplitude. Por 
isso mesmo, a noção de vida envolve tanto essência como existência. E a vida é ambígua justamente por se mover na tensão que a diferenciação entre o que se é e o que se deveria ser se instaura. Portanto, adotar uma abordagem unilateral é perder a riqueza que a constitui e, no limite, a ambiguidade da vida.

Nessa direção, é elucidativa uma passagem do final do seu curso publicado com o título História do pensamento cristão. Ele relata: “constantemente, eu tenho sido perguntando se sou um teólogo existencialista. Minha resposta é curta: meio a meio. Isso significa que para mim essencialismo e existencialismo se pertencem" (TILLICH, 1968, p. 541). A abordagem essencialista, predominante na história do pensamento ocidental, acaba por considerar em menor grau o estar-aí humano, ou como se fosse mera derivação de uma essência eternamente constituída. Por outro lado, a abordagem que privilegia a existência é sempre feita em contraste com alguma noção do que é o ser humano essencialmente. Além disso, ao recorrer à linguagem, não há como se evitar o recurso a categorias mais universais (TILLICH, 1968, p. 537-538), o que evidenciaria como não se pode prescindir da essência. De todo modo, há uma percepção, digamos, normativa do que é o ser humano. E essa noção acaba servindo de parâmetro para que se possa abordar a existência humana concreta.

Tillich parece ter razão nessa percepção quando se observa algumas dificuldades que os assim chamados filósofos existencialistas tiveram de enfrentar. Eles eram enfáticos na crítica à interpretação de que o ser humano seria detentor de alguma natureza previamente estabelecida. Antes, o ser humano se constrói a si mesmo por meio de suas decisões. Desse modo, ele existe e, ao existir, constitui sua essência. Para elaborar essa percepção, Heidegger acabou tendo de expressá-la da seguinte maneira: "A 'essência' do Dasein reside em sua existência" (HEIDEGGER, 2008, §9). Não deve passar desapercebida a formulação um tanto quanto paradoxal dessa expressão que sob a pena de Sartre tornou-se palavra de ordem do existencialismo. Ainda que o sentido é de que caso se queira falar de uma essência, ela somente pode ser referida ao processo dinâmico do se fazer a si próprio do existir humano, a própria formulação, no limite, não pode se evadir de uma noção essencial. 
Nas suas abordagens do ser-aí e da existência, tanto Heidegger como Sartre pressupõem certos critérios e elementos prescritivos. Tanto é assim que eles falam em existir próprio e impróprio, má-fé-, etc. Enfim, em alguma escala, parece que uma abordagem existencialista não pode abster-se completamente de se referir a certos elementos essenciais ou prescritivos. O que diferencia, entretanto, é o peso que se dá aos aspectos próprios do existir. Eles não são derivados de uma essência imutável, antes, possuem dignidade própria a ponto de poderem contrastar aquilo que se considera essencial. A existência não é apenas derivação de uma essência pré-fixada, mas se relaciona com a liberdade.

Enfim, a constatação do co-pertencimento entre essência e existência e a mistura entre eles mostra-se fundamental para a noção de vida como ambiguidade. Mas como, então, a mistura entre essência e existência determina a vida em sua ambiguidade? De um lado, a vida tem por intenção a manifestação de sua natureza essencial. No entanto, sob as condições da existência, ela se vê impedida de realizar isso plenamente. É na cisão entre esse intencionar e o não conseguir se realizar que emerge a ambiguidade. Ela emerge justamente entre o movimento de efetivação que a essência conduz e sua impossibilidade de realização, dadas as circunstâncias da existência. Em outros termos, a ambiguidade surge como ambiguidade diante da impossibilidade de efetivação plena da essência nas condições da existência. A ambiguidade aparece porque se almeja algo que se nunca se alcança. É no hiato entre esse desejar e o não alcançar que se instaura uma fissura, ou seja, a raiz das ambiguidades da vida.

Novamente, é possível encontrar ressonância desse rompimento em figuras religiosas. Em Morality and Beyond (1998), Tillich refere-se explicitamente aos dizeres de Paulo como expressão dessa percepção: "Porque não faço o bem que quero, mas o mal que não quero esse faço" (Romanos 7, 19). Afinal, o bem que se intenciona, esse não se realiza. Quer dizer, a vida intenciona efetivar sua essência. Mas, sob as condições da existência, isso que é intencionado nunca é realizado.

Por isso mesmo, a vida é movimento. Devido ao caso de que a essência nunca coincide com a existência, a vida está sempre nessa busca, perseguindo o seu ser. E ao fazê-lo, pode-se perceber que a vida é revestida de uma dinâmica própria. Ela não fica parada em si mesma, 
mas está sempre atrás de si. Para colocar em outros termos, em cada efetivação a vida está sempre em busca do seu ser. Uma vez que nenhuma efetivação consegue reunir essência e existência, ela sempre de novo deve buscar esse alvo. Nesse sentido, a vida é constante atividade. É movimento e busca.

Esse movimento se organiza de duas maneiras. Em primeiro lugar, há uma estrutura que marca esse movimento de maneira geral. Dialeticamente, a vida sai de seu centro. Aliás, para que ela possa efetivar sua essência, exige-se justamente que a vida saia de si mesma. Ela encontra a realidade e, nesse contato, a vida é enriquecida. Por fim, há o retorno a e sobre si mesma. A vida não se perde no âmbito da realidade, mas é também retorno para e sobre si mesma. Tillich denomina esses movimentos de autoidentidade, autoalteração e volta a si mesma. Não se trata de um movimento que se realiza uma única vez. Antes, ele ocorre constantemente, a todo o momento.

Se esse movimento possui essa estrutura geral, ele assume direções distintas segundo cada função do espírito. Na função moral, observa-se a repetição desse mesmo movimento da vida em geral, isto é, um movimento circular. Ele sai, mas retorna para o seu centro na constituição do indivíduo. No âmbito da cultura, o movimento é horizontal. Por isso mesmo, Tillich entende a cultura como relacionada à criatividade. Ela busca coisas novas, sem desconsiderar o que já está criado. Já no terceiro âmbito, na religião, esse movimento é vertical, pois a vida é também autotranscendência, dirigindo-se para além de si, para o incondicionado. Ainda que haja todas essas direções, é importante salientar que aquela estrutura de fundo permanece: é um sair de si, enriquecendo-se com o outro e retornando sobre si mesma. O que se altera é a direção do movimento.

O que é central dessa análise preliminar da vida humana? Do ponto de vista do seu método da correlação, interessa a Tillich mostrar as condições a partir de onde surgem as inquietudes da existência humana. E, em sua perspectiva, essas ambiguidades apontam para além de si. Isto é, a vida ambígua sonha em um dia não ser mais ambígua. Dessa maneira, a vida, nessa situação de ambiguidade, é uma busca por se reconhecer como condição a ser superada. 
As ambiguidades da vida em Paul Tillich e Ingmar Bergman

Assim, a partir desse olhar panorâmico por sobre a obra, podemos perceber alguns importantes aspectos sobre a questão da ambiguidade em Tillich. Em primeiro lugar, ela se articula com a formulação de questões que o ser finito, diante da debilidade de sua existência, levanta. Em termos do sistema de Tillich, isso significa dizer que a ambiguidade aparece como diagnóstico da condição humana, condição essa que o leva a elaborar certas perguntas e que exigem respostas no sentido de superá-la. Não se trata apenas de uma mera constatação da situação do ser humano. Esse aparato conceitual visa ler a condição humana a fim de se propor vias de respondê-la. Se esse traço é compartilhado pelas noções de finitude e alienação, o que se constitui como o específico da ambiguidade?

Essa busca, segundo Tillich, pode ser fragmentariamente saciada pelo que ele denomina de Presença espiritual. Como a Presença espiritual responde ao anseio pela vida sem ambiguidade? A ambiguidade é dirimida quando a vida é elevada à unidade transcendente para além das ambiguidades. Assim, por exemplo, o Espírito aparece na comunidade espiritual, superando a cisão de um eu com outro eu. Na cultura teônoma, a cisão entre sujeito e objeto é conduzida à sua unidade. E, por fim, na religião a autotranscendência rumo à unidade no incondicional é realizada. Com isso, a distância entre existência e essência, ainda que rara e fragmentariamente, é apagada nas suas diversas direções.

Pelo que foi dito aqui, notam-se duas linhas de força que, aparentemente, estão em direções opostas. De um lado, a ambiguidade se espalha para os mais recônditos âmbitos da vida, de modo que todas as funções são marcadas pela ambiguidade. Aliás, em parte, isso auxilia a explicar a dificuldade dessa parte da Teologia sistemática de Tillich. Uma vez que a ambiguidade se espraia até as mais recônditas dimensões da vida, Tillich se vê obrigado a tratar de uma infinidade de temas (desde o mundo inorgânico até as artes). O leitor desavisado tem a sensação de estar em labirinto, passeando por diversas áreas da vida humana, mas sem entender o porquê do autor ter feito essa opção. No entanto, não obstante a ambiguidade que tudo toca, a vida possui uma unidade. Por isso mesmo, ao início da seção que trata desse tema, Tillich rechaça a opção de Tomás de Aquino (seguido por outros) de falar em termos de níveis. Para ele, o ganho em se falar em dimensões reside em que, 
com isso, mostra-se que há distinções entre os diversos âmbitos da vida humana, mas essa diversidade não prescinde de uma unidade.

Enfim, com essas observações, é possível captar alguns elementos centrais para nossa proposta aqui. Pode-se observar, basicamente, em que consiste a noção de ambiguidade em Tillich, manifesta em três funções: moral, cultural e religiosa. Diante da complexidade e amplitude desse assunto, nesse texto vou me deter apenas na primeira função: a moral.

\section{As ambiguidades da vida na função moral}

Em que consiste a função moral na perspectiva de Tillich? A função moral, não se relaciona com o estabelecimento de leis, mandamentos e seu cumprimento por parte do ser humano, tampouco com padrões de comportamento esperados em uma dada sociedade ou cultura. Tillich entende que moralidade é a constituição do portador do espírito, isto é, a pessoa centrada. É importante a atenção a essa dimensão para que não se perca de vista o seu lugar fulcral. Afinal, se a cultura se revela como o âmbito da criatividade do espírito e a religião à autotranscendência para o que é último, isso somente é possibilitado diante da constituição desse portador do espírito. Em outro vocabulário, somente pode-se falar das funções do espírito, se há um "eu” que se constitui. Sem essa dimensão moral, a cultura e a religião tornam-se destrutivas e vazias, quando não inviáveis.

Uma vez que moral é colocada nesses termos, Tillich também reinterpreta a noção de imperativo moral. Ela não é uma ordenança formal, ao modo do imperativo categórico de Kant. Antes, "O imperativo moral é o mandamento de se tornar o que potencialmente se é, uma pessoa na comunidade de pessoas" (TILLICH, 1998, p. 656). É um poder ser do ser humano, segundo o qual ele pode se atualizar no tempo e no espaço. Em outros termos, o imperativo moral tem por conteúdo o tornar-se uma pessoa. É tornar-se um indivíduo. Mas esse indivíduo se torna o que é em meio a outras pessoas. Isso quer dizer, tornar-se um eu centrado e em relação com os outros.

Por isso mesmo, ato moral não significa se submeter a uma lei externa, seja ela uma lei humana ou divina. Antes, é uma lei própria do ser humano, no sentido de se tornar o que se é. Retomando a rela- 
ção entre essência e existência, o mandamento moral é o ser humano realizando sua essência. Dessa perspectiva, não é possível ser a-moral, pois não podemos abdicar de nos tornarmos nós mesmos. Aqui não há espaço também para a indiferença.

Se moral tem a ver com tornar-se o que se é, o antimoral configura-se como aquilo que é destrutivo. Nas palavras de Tillich,

Ele interrompe a centralidade da pessoa, dando predominância a tendências parciais, paixões, desejos, medos e angústias. O controle central é enfraquecido, muitas vezes quase removido. E quando isso acontece, e outras tendências parciais também aspiram predominar, o Eu é dividido e as tendências conflitantes o tornam seu campo de batalha (TILLICH, 1998, p. 657).

Em outros termos, o antimoral configura-se como o ir contra o tonar-se si mesmo. $\mathrm{O}$ ato antimoral acontece quando o ser humano luta contra a realização de sua própria essência. Esses casos podem ser associados biologicamente com a doença. Por essa percepção, pode-se notar como em Tillich a noção de essência, não obstante as articulações, tem uma centralidade maior do que nos assim chamados existencialistas.

Na moralidade, instaura-se uma cisão: individualização e participação. A individualização separa. Por outro lado, a participação aproxima, une. Por esse motivo, a autointegração se move entre o centro (o máximo da individualização) e a multiplicidade (o máximo da participação). Nesse movimento de saída de si mesmo em direção à realidade, a multiplicidade é integrada nesse centro, enriquecendo a identidade. Uma vez que se tem aqui um movimento, ele não tem garantias de que é bem sucedido. Aqui se manifestam os poderes destrutivos (antimorais). Nesse movimento de constituição do eu (e que envolve saída de si mesmo), o fracasso pode acontecer. E isso se dá, usualmente, de duas formas.

Em primeiro lugar, essa identidade, seja por incapacidade ou temor de se perder no múltiplo, fecha-se em si mesma. Nesse caso, o movimento é interrompido. Há um centro, mas ele não consegue incorporar em si a multiplicidade do que está "fora" de si por está fechado sobre si mesmo. Há identidade, mas ela é pobre e, de certa maneira, doente. Afinal, ela teme por aquilo que não conhece. 
O outro perigo, por sua vez, reside no extremo oposto. Há o movimento de saída de si. Mas, ao sair de si, essa identidade não mais retorna. Ela se perde na multiplicidade das coisas. Em outros termos, essa identidade se pulveriza na participação no outro. Neste caso, o processo vital perde o seu centro. No primeiro caso, o medo de se perder a si mesmo imobiliza. Já no segundo, a incapacidade de retornar a si mesmo dilui a identidade. De todo modo, a autointegração oscila entre esses dois pontos extremos: uma autoidentidade vazia ou uma autoalteração caótica.

Dado esse cenário, como se constitui, então, a centralidade do sujeito centrado? O ser humano não apenas está em um ambiente, mas habita um mundo. Ainda que ele se depare com limitações próprias de sua condição, ele percebe que tudo é potencialmente conteúdo de seu ser. Isso poderia efetivamente ser assim, não fosse um porém: ele se depara com outro eu. O outro se impõe como limite para que eu realize tudo aquilo que pretendo. Nesse sentido, tenho de estabelecer uma relação com ele, saindo de mim mesmo. Para o estabelecimento dessa relação, há o imperativo moral. Em outros termos, o outro se coloca como limite para a realização de todas as potencialidades. Com isso, cada ser centrado tem de estabelecer relação com outro eu. Posso, num primeiro impulso, querer reduzir esse outro a mero objeto, tentar dominá-lo. Mas, em algum momento, ele revela para mim sua subjetividade. Ele é também um eu centrado. Isso significa dizer que ele faz uma exigência incondicional: ele quer ser reconhecido como pessoa. Por conta disso, surge a necessidade do imperativo moral.

Outro ponto a ser esclarecido é que não se trata de qualquer encontro. Por exemplo, quando pego o ônibus e pago minha passagem ao cobrador, não há encontro no sentido que Tillich entende a noção. Afinal, aqui não há necessidade de envolvimento com a situação do outro, de empatia, de sentir-se como o outro. O outro é, em certa medida, a função que ele realiza, havendo inclusive certa objetivação dele. O encontro que interessa é aquele compassivo (de sentir com) que me permite diferenciar uma outra pessoa de uma coisa. É no saber como o outro se sente que o reconheço como pessoa. A questão passa a ser, então, que tipo de participação é essa. "Essa aceitação do outro eu mediante a participação em seu centro pessoal é o cerne do amor 
no sentido de ágape, o termo neotestamentário" (TILLCH, 2005, p. 506-507).

Assim, para a constituição da identidade, ocorre o movimento de saída de si mesmo. Nesse movimento, depara-se com o outro como limite e que exige ser reconhecido como pessoa. Isso é possível na medida em que se estabelece uma relação de empatia e de participação que leva à aceitação. Esse tipo de relação é o que se denomina de amor. Em outras palavras, para a constituição do eu, o tornar-se o que se é, uma vez que se relaciona com outras pessoas, passa invariavelmente pelo amor.

Dessa maneira, no caso de Tillich, o imperativo moral não se reduz a leis ou mandamentos. Não se trata de simplesmente buscar uma lei formal capaz de comandar essa relação. Antes, o nosso autor entende que a moral situa-se no âmbito do amor. $\mathrm{O}$ amor pode desempenhar esse papel por atender a duas demandas simultaneamente. Ele deve ter algo de absoluto. Enquanto imperativo moral, tem validade incondicional. Afinal de contas, esse imperativo moral mostra o nosso ser essencial, em oposição à alienação existencial. Por isso, tem valor absoluto. Até mesmo porque, se não fosse assim, faltaria o critério de julgamento para as ações. Se esse critério não está bem estabelecido, como diferenciar a vítima do algoz? Por outro lado, como o relativismo moral chama a atenção, esse imperativo moral não pode esquecer a concretude das relações históricas. De nada serve um mandamento moral que seja absoluto, mas que não considere a inserção na realidade concreta e histórica dos indivíduos. Para atender a essa demanda, Tillich encontra no amor a solução. O amor, segundo ele, tem algo de absoluto. Mas, ao mesmo tempo, tem certa abertura para ser atualizado em diversos contextos e necessidades. Ele não oferece prescrições fechadas.

Dessa maneira, o imperativo moral encontra no amor a sua formulação. Isso equivale dizer o seguinte: o eu centrado que sai de si mesmo em direção à realidade obedece às "leis" do amor. O fato de se referir ao amor como lei, ainda denota certa cisão. Afinal de contas, quando se precisa entender o amor como mandamento, isso significa que ele ainda é vivido a partir de uma lei. O ideal, para ele, é quando justamente não se precisa da lei. $\mathrm{O}$ amor acontece porque acontece. $\mathrm{O}$ indivíduo ama não porque é ordenado a fazer isso, mas porque ele se sente constrangido pelo próprio amor a amar. Esse ponto é de extrema 
importância. Afinal de contas, o amor não funciona somente como a fonte das demandas morais. Antes, ele é também a motivação para que se efetivem os atos morais. Dessa maneira, o tornar-se si próprio não é feito tendo por base a lei ou o mandamento que nos diz que devemos realizar nossa natureza essencial. Antes, no limite, é o amor que nos motiva na direção de realizá-la.

Há um elemento a se considerar aqui. O amor aparece como solução, afinal ele é entendido como reunião do que estava separado. Nesse sentido, se a ambiguidade aparece da cisão entre essência e existência, uma vez que o amor supera essa fissura, ele pode, se compreendido dessa maneira, resolver essa cisão. Nessa direção, a ambiguidade é aplacada.

De novo, cumpre lembrar, que a autointegração que esse amor proporciona é sempre um risco. Não há garantias de que essa autointegração moral possa acontecer, de que a lei do amor seja satisfeita. Pode ser que ele venha a fracassar. Por isso mesmo, não se pode garantir o sucesso na autointegração quando ficamos restritos à esfera da vida com suas ambiguidades. Uma resposta mais certa nessa direção é encontrada para além dessas ambiguidades, na Nova Vida. Como observado, na autointegração, oscila-se entre dois extremos: uma autoidentidade vazia ou uma autoalteração caótica. A resposta a isso ocorre por meio da integração do centro pessoal ao centro universal. Isto é realizado por meio da presença Espiritual. “A Presença Espiritual mantém a identidade do eu sem empobrecê-lo, e impele à alteração do eu sem destruí-lo" (TILLICH, 2005, p. 709). Não sem exagero, para Tillich, a presença espiritual efetiva de forma não-ambígua o essencial dentro do existencial.

Para tratar desse aspecto, Tillich emprega outro termo teológico, a noção de Graça. O que a graça realiza é "criar um estado de reunião no qual a clivagem entre nosso ser verdadeiro e nosso ser atual é fragmentariamente superada e a regra do mandamento é quebrada" (TILLICH, 1998, p. 681). Tillich destaca que a graça torna a lei superada pela seguinte razão. Se alguém ama, ele não precisa ser ordenado a amar. Ele já ama sem ser mandado. O desejo de união já está posto, de modo que a ordenança de amar se torna supérflua.

Para Tillich, elementos de graça permeiam a vida de todos, afinal eles são esses poderes curadores que permitem superar a cisão entre nosso ser essencial e nosso ser atual. Assim, "Onde quer que elementos da 
graça apareçam, o mandamento moral é preenchido" (TILLICH, 1998, p. 681). No entanto, essa graça comum (que aparece nos encontros com outras pessoas, etc.) é logo perdida. Com isso, volta a ambiguidade: passamos pela experiência da dor de nos sentirmos incapazes de sermos o que deveríamos ser. Nessa direção, Tillich entende que essas várias experiências da graça e sua penosa perda no cotidiano acabam por levantar uma pergunta mais ampla, que busca pelo sentido. Nessa busca pelo sentido, o ser humano acaba sendo dirigido para uma graça incondicional. Afinal, somente ela pode ser a resposta para nossa incapacidade de responder ao imperativo moral. Nos termos de Tillich, "Nós perguntamos diretamente pelo elemento de motivação moral, após termos experimentado seu efeito indireto como graça comum nos diferentes reinos da vida" (TILLICH, 1998, p. 681).

Dessa maneira, o que se desenha até aqui? A ambiguidade da vida emerge da cisão que se instaura por causa da tendência de realização do ser humano de seu ser essencial. No entanto, sob as condições da existência, ele não consegue efetivá-la. Desse descompasso surge a ambiguidade. Uma das funções centrais nas quais essa ambiguidade aparece é a moral. Moral aqui não é entendida como aplicação de leis ou imperativos categóricos, mas é tornar-se si mesmo e em meio aos outros. A constituição do eu, por sua vez, é possível por meio do amor e da graça. É somente aqui que as ambiguidades podem ser superadas, e os polos individuação e multiplicidade corretamente coordenados.

\section{As ambiguidades da vida no cinema de Bergman}

Ingmar Bergman, ao seu modo e se valendo da linguagem cinematográfica, retoma muitas dessas questões abordadas filosoficamente por Tillich. Não se pretende afirmar que eles dizem o mesmo, transformando o diálogo num monólogo. No entanto, há de se reconhecer que um quadro de problemáticas comuns os mobiliza. Para Kalin, "O tema de Bergman não é o ser como tal, mas o mundo moral - nós mesmos como seres humanos no século XX: o que é o mais profundo e o mais verdadeiro e essencial sobre nós, e qual o sentido que nós podemos encontrar para nossas vidas em face dessa verdade" (KALIN, 2003, p. 1). De certa maneira, essas são as questões de fundo que também ocupam Tillich em sua tarefa. 
De início, entretanto, cabe pontuar certas diferenças que se pretende explorar nesse diálogo. Como observado, para Tillich, o processo de constituição de si corre duplo risco. Ele pode se perder na multiplicidade. Ao sair de si, o eu não consegue se organizar novamente como um eu centrado. Por outro lado, há o risco do isolamento: este eu não consegue sair de si mesmo, restringindo-se a uma identidade vazia. Quando observamos vários filmes de Bergman, percebemos, em primeiro lugar, que esse último aspecto é o mais explorado. Em vários de seus filmes, há uma linha que se repete. Há um personagem isolado em si mesmo. Ele não consegue estabelecer uma relação significativa com o outro. Esta impossibilidade denota uma morte em vida. A alternativa seria, justamente, conseguir superar esse isolamento no sentido de uma relação significativa com o outro, saindo do isolamento e da solidão de si. No entanto, isso é raro e difícil. Neste ponto, a nosso ver, reside uma preciosa contribuição de Bergman para nosso tema.

Um filme que a princípio poderia parecer apontar na direção da perda de si na multiplicidade seria Persona. Na sua história principal, a atriz Elisabeth Vogler, ao interpretar Electra de Sófocles, fica catatônica. Poder-se-ia inferir que se trata justamente da perda de si na multiplicidade, nesse caso a atriz se perde no personagem que representa. No entanto, mais do que explorar a perda de si na autoexteriorização, Bergman ressalta justamente o isolamento da personagem. Num dos diálogos mais impressionantes do filme, diz-se:

Eu entendo muito bem. O inútil sonho de ser. Não parecer, mas ser. Estar alerta em todos os momentos. A luta: o que você é com os outros e o que você verdadeiramente é. Um sentimento de vertigem e a constante fome de finalmente ser exposta. Ser vista por dentro, cortada, até mesmo eliminada. Cada tom de voz, uma mentira. Cada gesto, falso. Cada sorriso, uma careta. Cometer suicídio? Nem pensar. Você não faz coisas desse gênero. Mas pode recusar a se mover e ficar em silêncio. Assim, pelo menos, não está mentindo. Você pode se fechar, se fechar para o mundo. Então não tem que interpretar mais papéis, fazer caras, falsos gestos.

Além de ocupar mais essa dimensão do fechamento em si mesmo, em Bergman, a religião apesar de sempre presente não se configura como alternativa ou resolução das ambiguidades da vida. Muito pelo contrário. A matriz religiosa mostra-se como fonte dessas crises. E, 
de certa maneira, sua produção cinematográfica segue essa tendência. De uma preocupação com relação à pergunta pelo silêncio de Deus, Bergman passa pela caracterização monstruosa de Deus para, por fim, defender o sagrado no humano. Portanto, o caminho é voltar-se para a subjetividade, para a relação com o outro.

Em outros termos, Bergman enxerga como problema central o isolamento do eu. Essa morte em vida somente pode ser superada quando o indivíduo se exterioriza, sai de si e se engaja numa relação com o outro. No entanto, se em Tillich esse movimento parecia quase natural, Bergman enfoca a dificuldade que aqui se coloca. Essa dificuldade se dá em dois níveis. Em primeiro lugar, o sair de si. Em segundo lugar, o próprio engajamento com o outro não é fácil. Para explorar essas ideias, vamos nos concentrar em uma produção fílmica de Bergman. Trata-se de Luz de inverno. Esse filme também aponta para o amor como possibilidade de redenção. A ambiguidade da vida não pode ser, de modo algum, superada. Ela ainda permanece. E mais. Mais do que resposta para as ambiguidades da vida, a religião pode ser um das fontes dessa ambiguidade. Isso, em si, não está contra uma tese geral de Tillich. Para ele, a religião é também ambígua. Mas, segundo ele, é ambígua quando não chega ao incondicional como tal. Já no caso de Bergman, a religião (no sentido de um conjunto de crenças e práticas) se mostra como fonte da ambiguidade não somente porque coloca o imperativo moral (cria uma essência que a existência não pode preencher), mas porque a religião não consegue, de maneira satisfatória, oferecer respostas realmente relevantes para as perguntas que emergem da ambiguidade que marca a vida. Nesse ponto, nota-se o quão distantes ambos se localizam: se para Tillich, a religião pode ser o caminho para uma vida sem ambiguidades (ainda que de modo fragmentado), para Bergman a religião é uma das fontes dessa ambiguidade. No caso específico de Luz de inverno, a possibilidade de conviver com as ambiguidades da vida sem se destruir não se dá via religião, mas via a negação de Deus².

2 Sobre esse filme, Bergman afirma: "Parece-nos tratar-se de uma complexidade de caráter religioso, mas é mais profundo do que isso. Sob o ponto de vista sentimental, o pastor está em vias de morrer. Sua via se desenrola sem amor, sem quaisquer relações humanas" (BERGMAN, 2001, p. 262). 


\section{Ambiguidades da vida em um mundo em ruínas}

Nattvardsgästerna (Os comungantes, também conhecido no Brasil com o apropriado título de Luz de Inverno), além de ser a produção de Bergman em que a dimensão religiosa aparece com mais evidência, também condensa muitas das suas principais indagações. Isso significa dizer que ela se constitui como porta de entrada para grande parte de sua produção fílmica, uma vez que muito da sua estrutura narrativa acaba por se repetir na pele de outros personagens ${ }^{3}$. Além disso, cabe ressaltar que esse era um de seus filmes prediletos, tendo conotação fortemente biográfica. Bergman, inclusive, assume que aspectos de sua trajetória biográfica se tornaram mais claros para ele mesmo a partir da realização desse filme.

O filme é mobilizado por uma questão, à qual o personagem principal (Tomas) não consegue responder. Ele se encontra num mundo em ruínas. Mais especificamente, mesmo sabendo que não irá lograr sucesso, o pároco insiste em se levantar contra o silêncio de Deus, esperando uma resposta capaz de lhe reconstruir o mundo e the dar novo sentido. No entanto, nessa busca somente encontra o abandono, a frieza, o amor que não deseja, isto é, a morte e a solidão. O silêncio de Deus permanece e ecoa pelo filme, afinal o abandono não é superado. Mesmo quando flerta com o ateísmo, uma saída feliz, Tomas não conseguir ir adiante. Ainda está por demais vinculado ao mundo que desabou. Uma vez que a centralidade da narrativa está no silêncio de Deus como tal, mas no sentimento de abandono, enquanto esse sentimento não é superado, ainda persiste a pergunta pelo porquê de Deus não falar. Enfim, Tomas parece reconhecer que a pergunta por Deus exige outro tipo de resposta, a saber, o amor. No entanto, ele hesita em dar esse passo. Em determinados momentos da narrativa, tem-se a impressão de que ele superará o enclaustro no qual se encontra, direcionando-se à relação amorosa com Märta. No entanto, ele acaba retornando para dentro de si mesmo. Essa oscilação, entre superar ou permanecer nesse estado de abandono, concede uma moldura à trama.

3 A abordagem aqui é proposta é debitária da leitura e da proposta de Kalin, 2003. Ainda que não a tome como canônica, muitos dos contornos da interpretação foram inspirados nessa profícua fotografia da estrutura que anima os principais filmes de Bergman. 
As ambiguidades da vida em Paul Tillich e Ingmar Bergman

Deus e eu vivíamos num mundo organizado onde tudo fazia sentido. Quero que saiba que não sou um bom sacerdote. Tinha fé numa imagem improvável e particular de um deus paterno. Um deus que amava a humanidade, mas a mim acima de tudo. Percebe que erro monstruoso eu cometi? Um sacerdote ignorante, infeliz e ansioso. Fazia minhas preces para um deus-eco... que me dava respostas agradáveis e bênçãos tranquilizadoras. Toda vez que confrontava Deus com questões reais, percebia... que Ele se transformava em algo feio e revoltante. Um Deus-aranha, um monstro.

Em que medida o mundo construído pela religião se mostra insuficiente diante de certas perguntas da vida?

A religião pretende, em grande medida, colocar-se como discurso capaz de instaurar sentido. Dessa maneira, diante da insignificância da existência, o abismo com o qual o ser humano constantemente se depara, constroem-se castelos para que se possa habitar com relativa segurança. Esses construtos buscam justamente isolar de todo o perigo que assombra, oferecendo conforto. É graças a essas construções que o ser humano pode se sentir em casa no mundo. A religião constrói abrigos, oferece conforto, torna o mundo habitável e a vida familiar. A ordem que ela cria se estabelece na direção de mostrar como as coisas não são destituídas de sentido, mas acontecem segundo um propósito. Com isso, exclui-se o absurdo que permeia a vida e ela se tornaria compreensível. Em suma, dar ordem é estabelecer sentido que, por sua vez, significa tornar as coisas compreensíveis e, portanto, suportáveis. Bergman reconhece esse papel da religião ao afirmar: "Este mundo está constantemente em busca de novos projetos, de novas estruturas e de novos sistemas que possam, parcialmente ou inteiramente eliminar estas impressões de solidão. Sem isto, os sistemas religiosos seriam inconcebíveis" (BJÖRKMAN, 1977, p. 137).

Pelo trecho do filme acima citado, observa-se que o mundo que Tomas habitava pressupõe que há um Deus de amor. Mais do que isso. Esse Deus se preocuparia com o bem estar do ser humano. Mas, não somente de toda a humanidade. Esse Deus se preocupa com indivíduos particulares. Quando reconhecida como ilusão, essa compreensão mostra sua verdadeira face: uma noção monstruosa de Deus.

No entanto, no caso de Luz de inverno, Bergman parece contrapor a eficiência desse discurso no que toca à sua capacidade de apaziguar 
(ou mesmo eliminar) esse vazio. Como isso se dá? Quando esse discurso é contraposto a experiências limítrofes, eles mostram o que realmente são: meras ilusões.

$\mathrm{Na}$ concepção de Bergman, o discurso religioso se mostra incapaz de oferecer respostas a perguntas existencialmente relevantes. No filme, são mencionados dois exemplos. Em primeiro lugar, Tomas, o sacerdote em crise, se lembra do tempo em que foi pastor em Lisboa, na época da Guerra Civil espanhola. Enquanto vivia abrigado em seu mundo de conforto, a concepção de Deus que sustentava parecia lhe oferecer ordem e tranquilidade. As coisas funcionavam bem. Ele se sentia em casa no mundo. Entretanto, ao ser contrastado com a realidade, isto é, com a crueldade e a maldade, essa ordem entrou em colapso. Ele se deu conta de que aquela compreensão de Deus não oferecia explicação satisfatória para suportar a existência do mal que se colocava diante dos seus olhos com uma evidência incontestável. Além dessa experiência, a morte de sua esposa o lança no abismo da falta de sentido. É esse o amor de um Deus que é amor? A ausência de respostas resulta num mundo frio, silencioso, quase desértico.

Diante da insuficiência da religião em realizar aquilo que se propõe, isto é, a oferecer ordem para o mundo, Tomas se vê movimentando nos escombros das antigas edificações de sentido, que agora são reconhecidos como fantasiosos. Nesse sentido, caso a comparação seja válida, ele pode ser tido como expressão do niilismo do ser humano moderno. A religião não mais é capaz de dar ordem ao mundo. No entanto, a princípio, não surge nada em seu lugar capaz de substituí-la e tornar essa realidade habitável. Ele fica como que suspenso, destituído de explicação; incompreensível para quem vive sob os escombros do mundo em desordem, mas ainda amarga certa nostalgia. Essa percepção parece se justificar a partir de afirmações do próprio diretor em entrevistas. Numa delas, ele afirma:

Na Suécia, vivemos na ilusão de que temos tudo. Mas no meio dessa vida plena, nós temos um grande vazio, a ilusão perdida de Deus, chame isso como quiser, uma necessidade de segurança material, social. É esse vazio e tudo o que os homens inventam para preenchê-lo que eu descrevo em filmes, e creio que é um modo de fazer filmes engajados nos problemas contemporâneos e mesmo no único problema fundamental: o de dar 
As ambiguidades da vida em Paul Tillich e Ingmar Bergman

sentido espiritual ou humano a uma civilização de felicidade material. Em todo caso, é meu problema pessoal. Não me peça para falar de outra coisa, eu não saberia (ARMANDO apud BERGMAN, 1988, p. 47).

O filme também não deixa de abordar como as instituições podem deixar de serem ordenadoras ou, pelo menos, como elas deixam de desempenhar um papel relevante na organização do mundo. Uma vez que todo o filme acontece no interior de uma igreja, nada mais natural que a instituição em relação à qual isso apareça seja a própria igreja. $\mathrm{Na}$ cena inicial, talvez a mais longa a retratar um culto ou uma missa na história do cinema (são mais ou menos 10 minutos), nota-se como os comungantes e a criança presente no culto estão dispersos. Isso é apresentado não por meio de palavras ou diálogos, mas pelo comportamento dos participantes. Ainda que a câmera feche em suas faces, seus olhares não se dirigem para ela. Os comungantes parecem estar olhando para outra coisa; seus pensamentos parecem estar distantes, em outro lugar. O que acontece ali lhes soa existencialmente pouco relevante, para não dizer desinteressante.

O personagem que dá vazão a essa postura com menos inibição é o organista Frederik Blom. Ao tocar os hinos do culto, nota-se a forma mecânica como realiza seus atos, bem como seu desinteresse. Os seus bocejos dão a impressão que ele quer mesmo é que aquela missa se acabe logo. Enfim, a instituição religiosa se mostra de um peso insuportável. O intuito de reforçar essa sensação explica o porquê de Bergman ter inserido essa longa sequência no início do filme. Ao que parece, ele procura criar no espectador esse mesmo tédio que toma conta daquela igreja, que há muito deixou de ser relevante na construção de mundo de seus participantes.

Em outros termos, não nos parece que Bergman nega o poder tranquilizador e ordenador da religião. No entanto, ele aponta um limite claro: ao ser contrastada com perguntas existencialmente relevantes, essa estruturação do mundo entra em colapso. Aliás, um diálogo de Através de um espelho pode ser esclarecedor. Nele se diz:

Sabe, Karin... traçamos um círculo imaginário ao nosso redor para afastar aquilo que não faça parte do nosso jogo secreto. Cada vez que a vida 
rompe esse círculo, os jogos se tornam insignificantes e ridículos. E então construímos um novo círculo e novas defesas.

Dessa maneira, é como se fosse uma necessidade para a vida estabelecer esses círculos de proteção. Eles garantem um lugar a salvo do caos. No entanto, essas proteções também vão revelando sua fragilidade. Por vezes, não conseguem salvaguardar os seres humanos. A desordem se instaura, colocando a necessidade de se construir novos lugares de proteção. Um passo nesse movimento se encontra justamente no reconhecimento de quão ridículos círculos de proteção anteriores agora parecem. Mas, não se pode abdicar complemente deles. Quando a desordem se instala, até mesmo para a manutenção da vida, torna-se necessário criar outro círculo. Sempre sabendo-se de sua provisoriedade.

\section{A condição humana do abandono}

Ser abandonado quando precisa contar com alguém. Isto deve ser extremamente doloroso. Mas o pior ainda estava por vir. Quando Cristo foi pregado na cruz, em meio ao sofrimento... ele gritou: "Deus, meu Deus! Por que me abandonastes?" Ele gritou tão alto quanto podia. Ele achou que seu pai o havia abandonado. Achou que tudo que havia pregado era mentira. Nos momentos que antecederam sua morte, Cristo teve dúvidas. Certamente, aquele deve ter sido seu maior sofrimento. Deus ficou em silêncio...

Uma vez que a religião se mostrou insuficiente na elaboração de uma totalidade significativa, habita-se um mundo destituído de sentido. No entanto, esse habitar não é simplesmente um estar-aí, sem maiores implicações. Antes, ele possui uma conotação fortemente existencial, visto que ele é movido pelo sentimento de ser abandonado. Aliás, esse parece ser o traço mais fundamental desse filme. O abandono permeia a vida de todos os personagens, especialmente de Tomas. E mais, o fato de se sentir abandonado por Deus acaba fazendo com que ele também reproduza essa postura em relação a outras pessoas, numa atitude indiferença em relação a elas. Ou seja, o insucesso na constituição de si do personagem se deve, justamente, por conta de sua tradição religiosa. Uma vez que se sente abandonado, não consegue sair de si mesmo e estabelecer uma relação significativa com o outro. 
As ambiguidades da vida em Paul Tillich e Ingmar Bergman

Como fica explícito já no clássico $O$ sétimo selo, a pergunta em torno do silêncio de Deus é expressamente tematizada por Bergman. $\mathrm{Na}$ película de 1957, o cavaleiro que retornava das cruzadas e se deparava com os horrores provocados pela peste negra indagava por Deus. Onde estaria ele em meio aquele horror? Enquanto a morte se manifestava e acompanhava o cavaleiro de perto, Deus não se pronunciava. Ficava recluso em seu eterno e gélido silêncio. Novamente em Luz de inverno, esse tema retorna com bastante evidência. Tomas, em diversos momentos, diz em tom de lamento que Deus está silencioso. Mais do que isso. É justamente esse silêncio de Deus que é tido como o responsável pelo vazio que se instaura, pela ausência de repostas, pelo desmoronamento do mundo construído. Portanto, mais do que propriamente o silêncio de Deus, o que preocupa o cineasta é a reverberação desse silêncio no âmbito do humano: o sentimento de abandono, que assume várias figuras e formas no decorrer do filme.

Em termos estéticos, há o uso muito criativo da iluminação. Para destacar o caráter sombrio desse sentimento, o contraste entre o preto e branco do filme é acentuado nas cenas em que Tomas sofre com ele. Nota-se que em todo filme ele sempre está vestido com cores escuras, sendo que em muitas das cenas ele se encontra na penumbra, de modo que a se fundir com a escuridão do cenário. Já em sequências nas quais surgem as oportunidades de virada, raras e tênues como a luz de inverno em países escandinavos, nota-se que as imagens ficam mais claras, sem perder o aspecto acinzentado.

Esse abandono aparece também no corpo. É como se esse abandono crescesse de dentro para fora, extravasando o âmbito meramente psicológico para ganhar visibilidade por meio da gripe que o acomete. Desde o começo do filme, ele é apresentado em estado de prostração. Não se trata apenas de um simples resfriado, mas de uma manifestação somática que o deixa abatido. O seu corpo também padece desse autoisolamento. Novamente, vemos ressonâncias das comparações que Tillich estabelece entre o insucesso nesse processo de constituição do eu com a doença.

Esse movimento não se circunscreve ao mundo próprio de Tomas, mas afeta também seu mundo circundante. O inverno gélido e sem vida não se configura apenas como cenário onde as ações acontecem. Ele é 
a exteriorização espacial do inverno que acomete psicologicamente o pastor luterano. Esse ambiente glacial também indica a frieza com que ele trata as pessoas ao seu redor. De certa maneira, o silêncio de Deus, com o seu decorrente sentimento de abandono, leva Tomas a se fechar em si mesmo. No começo do filme, ele recusa o conselho de Aronsson (tesoureiro da igreja) de solicitar que alguém o auxilie nas tarefas domésticas. Ele se isola das demais pessoas, furtando-se a estabelecer qualquer tipo de relação mais aprofundada ou significativa.

Esse abandono que permeia o comportamento de Tomas é visto como decorrência de uma religião doentia. Essa constatação é feita por Märta. Num dos diálogos, ela menciona que não consegue compreender essa religião neurótica. Inclusive, ela diz que nunca foi acometida por questões de natureza religiosa, como ele. Os símbolos religiosos não tiveram e não têm papel relevante para ela, de modo que em suas memórias sua família era marcada pela união. Eles eram felizes. E, talvez assim o fossem, justamente por terem construído seu mundo sem as referências neuróticas da religião de Tomas. Ao contrário de Tomas, que se fechou em si, ela se encontra aberta aos outros, inclusive ao próprio pastor.

Diante desse sentimento que o consome, Tomas encontra uma válvula de escape na execução do seu papel social. Ainda que mecanicamente, ele conduz os cultos. O desejo há muito se evadiu dele. As palavras da liturgia se sucedem uma à outra. Ele cumpre o que deve fazer. Isso é, de certa maneira, um modo de se continuar vivendo, mesmo quando não há mais razão para isso.

Por fim, ainda que esse abandono seja mais marcadamente presente na figura de Tomas, ele é, de alguma maneira, perceptível em outros personagens do filme. O pescador Jonas, por exemplo, sente-se ameaçado pelo mundo e não consegue encontrar amparo, o que o leva a cometer suicídio. A sua esposa, grávida de outro filho, ao receber a notícia da morte do marido logo observa que, a partir de agora, estaria sozinha. Está por sua conta a educação das crianças, inclusive daquela ainda por vir.

A própria Märta, apesar de demonstrar uma abertura para as relações amorosas, também não parece em situação tanto melhor. Ela busca um sentido para sua vida. Esse sentido é encontrado na tarefa 
do imperativo moral de amar alguém. Por fim, na fala que parece ser central no filme e utilizada como epígrafe dessa parte do artigo, Algot Frövik diz que as maiores dores de Cristo não foram as dores físicas. Ele mesmo, por sua artrite, não somente as suportava por algumas horas, mas por anos a fio. A pior dor não é essa, mas a de se sentir abandonado: abandonado por seus seguidores, por seus discípulos e, principalmente, por seu próprio pai. Essa é a pior dor que pode acometer alguém. Esse é o sofrimento mais cruel pelo qual ele passou. A sua paixão não é o sofrimento na carne, mas o abandono que sente em seu espírito. Mais do que à figura de Cristo, ele parece estar se referindo justamente à condição humana.

\section{Possibilidades de redenção}

Você não conseguirá sozinho. Não sobreviverá, Tomas. Nada pode salvá-lo. Você se odiará até a morte.

Ainda que esteja mortificado, é possível encontrar caminhos para a superação do abandono decorrente do silêncio de Deus. A redenção não acontece por força própria daquele que se encontra nesse estado, mas depende da ação de outro. O caminho possível se dá pela renúncia à pergunta pelo silêncio de Deus, para se voltar para a imanência das relações intersubjetivas.

Em outros termos, a solução para a superação do abandono se encontra no amor. No entanto, é preciso cautela. Apesar de sua solução apontar para algo similar ao que se vê em Tillich, seus filmes ressaltam mais o caráter conflitivo da relação intersubjetiva do que propriamente alguma pretensa harmonia. As relações subjetivas são um inferno. Mas, é o caminho que resta ao ser humano para superar o sentimento de abandono e o fechamento em si mesmo. Se viver com os outros é um martírio, viver sozinho é ainda pior. Para compreender essa possibilidade de redenção é preciso seguir os dois passos que o constituem. Especificamente em Luz de inverno, o primeiro momento consiste em se negar Deus (a fim de que a própria ideia de silêncio perca seu sentido) para que, num segundo momento, o ser humano possa encontrar nas relações intersubjetivas a superação desse sentimento de abandono. 
A fim de compreender esse momento de libertação em relação a Deus, é preciso estabelecer uma diferença sutil, mas marcante. O tema do silêncio de Deus nos filmes de Bergman não pode ser tomado como sinônimo de ateísmo. Trata-se, nesse caso, de duas categorias distintas. Também, em grande parte de seus filmes, a busca por Deus não se reduz ao conhecimento. Isso quer dizer o seguinte: o que se pretende encontrar não são argumentos logicamente encadeados que atendam às demandas do intelecto. Antes, o Deus requerido é aquele capaz de responder à solidão humana. Por isso mesmo o silêncio de Deus é sentido como abandono, não tendo consequências epistemológicas, mas existenciais. Num sentido bem preciso: ele afeta a existência e se relaciona com a solidão.

Um momento chave do filme, no qual a luz de inverno atravessa o vitral da igreja e ilumina a cena, acontece justamente quando Tomas assume uma postura de negação da existência de Deus. Mas é uma luz de inverno. Tênue e passageira. Logo se esvai. Quando isso acontece, ele pode bradar:

Se Deus não existe, isso realmente faria alguma diferença? A vida se tornaria compreensível. Seria um alívio. E a morte seria a extinção da vida. O fim do corpo e do espírito. Crueldade, solidão e medo, todas estas coisas seriam claras e transparentes. O sofrimento é incompreensível, portanto não exige explicação. Não existe um criador. Nenhum provedor da vida. Nenhum desígnio.

Deus... Por que me abandonastes? Agora estou livre. Finalmente livre. Tive esperança...

Chama a atenção que ele levanta o ateísmo como possibilidade. Ele se pergunta: “E se Deus não existisse...." Caso essa hipótese se confirmasse seria um alívio. Afinal de contas, a negação de Deus trataria em si o assumir a vida como absurda. É mais fácil conviver com o absurdo da vida (e suas ambiguidades?), com o fato de que o mundo é inerentemente mal do que assumir que há um Deus, mas que deixa o ser humano abandonado, lançado no sofrimento e na solidão. Nesse caso, o ateísmo aparece como solução para o dilema do silêncio de Deus e o sentimento de abandono. Nota-se que Bergman não necessariamente tira como consequência desse ateísmo a afirmação do ser humano. Ele diz apenas que as coisas se tornariam mais aceitáveis, suportáveis. In- 
clusive, com isso a própria ideia de abandono perderia o significado. Afinal, se não há Deus, que sentido faz em se falar de abandono? Como aquele que não existe poderia abandonar alguém?

Nessa passagem é possível notar uma mudança de postura de Bergman em relação àquilo que era expresso por meio do cavaleiro cruzado em $O$ sétimo selo. Ao se confessar para a morte, imaginando se tratar de um sacerdote, Antonius Block diz: "Eu choro para ele no escuro, mas parece não ter ninguém lá. Talvez não tenha ninguém lá. Então a vida é um terror sem sentido". Num filme que também tematiza o silêncio de Deus, o ateísmo soa como tão ou mais desesperador do que o silêncio. A postura aqui é a de que se Deus não existe, então as coisas se tornam sem sentido. A vida, ao invés de encontrar o solo próprio da liberdade humana para se desenvolver, torna-se um horror. No entanto, já em Luz de inverno, o diretor parece assumir que é justamente a negação de Deus que tornam as coisas mais inteligíveis e, portanto, mais suportáveis. Afinal, com isso pode-se encontrar a santidade onde ela realmente habita: no humano.

Como observado, esse filme possui clara e forte conotação biográfica. Nessa direção, pode-se observar como o seu desenvolvimento, interpretado da maneira como aqui se propõe, aproxima-se muito de uma confissão que Bergman faz sobre sua relação com a questão de Deus. Ele parte da situação de ambiguidade que o silêncio gera, passando para o caráter libertador do reconhecimento de que não há Deus:

Em toda minha vida consciente eu tinha lutado contra uma relação com Deus que era um tormento e uma tristeza. Fé e descrença, castigo, misericórdia e reprovação eram realidades insanáveis. Minhas preces exalavam angústia, apelo, pragas, agradecimento, esperança, tédio e desespero: Deus falava, Deus se calava, "Mas não me impeça de contemplar Seu rosto". As horas perdidas me deixaram uma mensagem tranquilizante: você nasceu sem intenção, vive sem um sentido, porém o viver é seu sentido. Quando morrer, vai apagar. Do ser você se transforma no não-ser. Um deus não tem necessariamente que morar entre os nossos caprichosos átomos. Minha compreensão trouxe consigo certa segurança, que decididamente empurrou para longe angústia e tumulto. Entretanto, nunca neguei minha outra (ou primeira) vida, minha vida espiritual (BERGMAN, 2013, p. 216). 
Esse caráter libertador da negação de Deus abre para a afirmação da relação com o outro, mais especificamente para as relações intersubjetivas e, posteriormente, para a afirmação da santidade no humano. Se há um Deus que se mostra ausente e se, no limite, não há Deus, a saída é assumir a relação com os outros. É justamente no esquecimento dessa questão do abandono de Deus que se pode encontrar um primeiro movimento no sentido de se encontrar a redenção.

Nas palavras de J. Kalin, "o que acontece nesses 'espaços encantados' é sempre alguma forma de compartilhar a vida juntos, de apoiar e de cuidar um do outro" (KALIN, 2003, p. 25). É preciso transcender essa busca por Deus em direção ao ser humano, na relação amorosa. Somente no humano é possível achar uma solução para problemas metafísicos. Para Bergman, não há respostas transcendentes. Antes, a saída para os anseios humanos se encontra na terra, na relação com outros seres humanos. Nas palavras de Robert Lauder,

A filosofia de Bergman é a de que Deus não existe ou, pelo menos, está em silêncio e nossa única esperança é amor humano interpessoal. A sua morte e ausência nos obriga a olhar para a redenção e salvação à parte de Deus. Amor interpessoal é redenção que podemos esperar (LAUDER, 1987, p. 51).

Mais do que a dificuldade da saída enquanto tal, Luz de inverno aponta o embaraço da própria decisão nessa direção. O tema das relações intersubjetivas é tratado em outros filmes de Bergman, como, por exemplo, Cenas de um casamento, mostrando que a relação amorosa não é tranquila e harmoniosa, mas essencialmente conflitiva. Mas aqui, a indecisão de Tomas é indício de como é difícil se libertar das ruínas de um mundo destituído e autoisolamento. O movimento de redenção, isto é, de saída do círculo de segurança e se apostar na relação com o outro não é tarefa simples. O filme mostra o quão complexo é existencialmente aquele movimento que Tillich elabora teoricamente.

Em alguns momentos do filme, Tomas é confrontado com essa possibilidade. Por vezes, como na cena descrita acima em que afirma o ateísmo, ele parece caminhar na direção de sua redenção. No entanto, logo na sequência regressa à postura anterior. Essa oscilação, entre a aposta na relação amorosa e a permanência num mundo em 
ruínas, marca toda a película. Nessa direção, há duas cenas emblemáticas. Quando Tomas e Märta estão na escola, ele diz que não a ama. Isso é dito de maneira agressiva. No entanto, antes de partir para suas atividades pastorais, ele a convida para ir junto de si. Quer dizer: ao mesmo tempo em que recusa a alternativa de encontrar apoio no outro, não demonstra estar realmente disposto a descartar essa alternativa. A outra cena acontece ao final do filme. Por mais que haja essa rejeição de Märta por parte do pastor, ela é a única pessoa presente no culto da tarde. Nos diálogos anteriores ao culto, os presentes destacam o valor especial que ela possui para Tomas. A forma mecânica ainda permanece, mas ele celebra o culto somente para ela. Ele bem poderia cancelar o culto por falta de frequentadores. No entanto, ele o celebra e o faz apenas para Märta. Enfim, ao final, reaparece a dificuldade dessa decisão que leva à redenção.

Essa decisão parece difícil por uma série de causas. Uma delas se liga justamente com a situação de abandono. Como esperar que alguém que se encontra nessa situação de abandono possa, por sua livre iniciativa, romper com a cadeia de reprodução desse desprezo e optar pelo amor? Como Märta observa, não é algo que se conquista sozinho. O abandono gera o fechamento de Tomas em si, até mesmo como autodefesa. Sendo assim, como esperar o amor de alguém que não se sente amado?

Em segundo lugar, há a complexidade da figura de Märta. Ao mesmo tempo em que ela se mostra cuidadosa com Tomas, possui uma personalidade autoritária. Ela se acha portadora da missão de prover a salvação de Tomas e investe toda sua energia nisso. Seguindo uma tendência nos filmes de Bergman, a personagem feminina aparece como a parte forte da relação. Em seus filmes, as mulheres são geralmente apresentadas com esses traços, ao passo que os homens são inseguros e angustiados. Nesse caso, ao mesmo tempo em que ela assume essa postura de comando, ela se submete a ele, justamente por se achar portadora de sua salvação. Desse modo, ela parece ser um monstro, mas tem algo de humano. De todo modo, não é uma pessoa fácil de ser amada.

Esse filme trata mais da dificuldade de tomar a decisão. Posteriormente, Bergman enfatiza de modo ainda mais claro o sagrado do humano. 
A respeito do desenvolvimento de sua compreensão de Deus, ele diz algo muito parecido com uma fala de Confissões privadas (de 1996):

É o resultado de uma evolução progressiva durante estes anos e a esta desagregação total, sucedeu, digamos, para simplificar, a crença em uma forma de santidade inerente ao ser humano. É a única santidade que existe realmente. Sua origem é unicamente terrena. E é isto que quer exprimir a sequência fina, o amor como única forma concebível de sagrado (BJÖRKMAN, 1977, p. 136).

\section{Conclusão}

Ainda que a abordagem de Bergman não se estruture tão sistematicamente se valendo de um aparato conceitual tão elaborado como se percebe em Tillich, ela não se mostra menos profunda. Por isso mesmo, nossa proposta aqui não foi a de buscar na produção artística questões que o ser humano contemporâneo levanta a fim de mostrar como a religião pode respondê-las. Antes, a intenção foi mostrar como a produção cinematográfica trata de questões similares, mas à sua maneira. Os dramas humanos são encarnados nos personagens. Aqui está a riqueza que parece escapar à linguagem conceitual da filosofia: abordar temas amplos e universais, mas sem perder sua dramaticidade que acomete cada indivíduo. Por isso, ao assistir esses filmes, conseguimos nos identificar com os personagens. Se de um lado, Bergman apresenta os limites da religião em estabelecer respostas, por outro, mostra com bastante contundência as dificuldades daquilo que em Tillich parece ser um processo quase natural, de saída de si mesmo.

Para sistematizar, pode-se notar que a ênfase de Bergman está no isolamento do eu. Esse sentimento de abandono, mais do que um elemento que leva o ser humano em direção à religião, é interpretado por ele como resultante do construto das tradições religiosas. É como se elas se mostrassem incapazes de dar respostas satisfatórias a perguntas realmente importantes. Portanto, resta ao ser humano a busca pelo sentido no amor, no engajamento na relação com o outro, reconhecendo aqui a santidade. Se a graça pode ser encontrada, ela reside no humano. Aqui, podem acontecer momentos de graça. São efêmeros, mas não inexistentes. Mas, acima de tudo, Bergman ajuda a compreender como esse processo é difícil. Com isso, não queremos dizer que Tillich não 
As ambiguidades da vida em Paul Tillich e Ingmar Bergman

reconheça isso. Apenas, queremos indicar que a sua linguagem mais sistemática não permite entrever como o drama humano se inscreve aqui. Nesse sentido, Bergman se mostra como interlocutor que auxilia na percepção da luta que aqui se dá.

\section{Referências}

ARMANDO, Carlos. O planeta Bergman. Belo Horizonte: Oficina de Livros, 1988.

BERGMAN, Ingmar. Lanterna mágica. Autobiografia de Ingmar Bergman. São Paulo: Cosac Naify, 2013. . Imagens. São Paulo: Martins Fontes, 2001.

BJÖRKMAN, Stig. O cinema segundo Bergman. Rio de Janeiro: Paz e Terra, 1977.

BRANCO, José Luiz. O Bergman que vi com Heidegger: cinema e fenomenologia em diálogo. São Paulo: Editae Cultural, 2014.

HEIDEGGER, Martin. Ser e tempo. Campinas, SP: Editora da Unicamp; Petrópolis, RJ: Editora Vozes, 2012.

JONHSTON, Robert K. Reel Spirituality: theology and Film in Dialogue. Grand Rapids: Baker Academic, 2000.

KALIN, Jesse. The Films of Ingmar Bergman. Cambridge: Cambridge University Press, 2003.

LAUDER, Robert. Ingmar Bergman: The Filmmaker as Philosopher. Philosophy and Theology, 2, p. 44-56, 1987.

LIVINGSTON, Paisley. Cinema, Philosophy, Bergman: On film as philosophy. Oxford: Oxford University Press, 2009.

PIEPER, Frederico. Religião e cinema. São Paulo: Fonte Editorial, 2015.

SANTOS, Joe Marçal Gonçalves. Uma teologia da imagem em movimento a partir da obra de Andrei Tarkovski. 2006. Tese (Doutorado em Teologia)

- Escola Superior de Teologia, São Leopoldo, 2006.

SKRADE, Carl. "Theology and films". In: COOPER, John Charles; SKRADE, Carl. Celluloid and symbols. Fortress Press, 1970.

TILLICH, Paul. História do pensamento cristão. 4 ed. São Paulo: ASTE, 2007. . Teologia sistemática. 5 ed. revista. São Leopoldo: Sinodal, 2005.

. Morality and Beyond. (1963). In: STURM, Erdmann. (Hrsg.). Main Works - Hauptwerke. Band 3: Sozialphilosophische und ethische Schriften. Berlin; New York: Walter de Gruyter; Evangelisches Verlagswerk, 1998, p. 651-712. 